\title{
Management practices and production constraints of central highland goats in Emba Alaje District, South- ern Zone, Tigray, Ethiopia
}

\author{
Tsegay Tkue Gebrewahd ${ }^{1 *}$,Abadi Meresa and Niraj Kumar ${ }^{1}$ \\ ${ }^{1}$ College of Veterinary Medicine, Mekelle University, P.O.Box: 2080, Mekelle, Ethiopia \\ *Corresponding author: Tsegay Tkue Gebrewahd, Email: tsegay1984t@gmail.com \\ https://dx.doi.org/10.4314/evj.v21i2.1
}

\begin{abstract}
A cross-sectional study was conducted from March to June 2016 on randomly selected 250 households who reared goats in Emba Alaje District to assess management practices of central highland goats and their major constraints. A pretested and semi-structured questionnaire was used to collect the required data. Out of the total respondents, $213(85.2 \%)$ were male and $38 \%$ of them had a basic education. Almost all $249(99.6 \%)$ of the respondents practiced a mixed crop livestock production system, and majority of them (85.2\%) reared goats for an immediate cash source. About $78.8 \%$ of the respondents had a separate farming area for their goats. Regarding the feeding management, majority of the respondents, $223(89.2 \%)$ used a communal grazing/browsing area. Provision of supplementary feeds for goats was not common, and the breeding system was almost uncontrolled. Majority of the respondents 154, (61.65\%) did not select buck for breeding, and $88(35.2 \%)$ of them did not know the source of the bucks that mated their goats. In the present study, $100 \%$ of the respondents complained that, there were diseases that affected the health and production of their goats, of which $33.6 \%$ of the respondents complained, pasteurellosis as one of the major goats' diseases in the study area. Feed shortage (36\%) and diseases (33.6\%) were among the major constraints raised by the respondents. Therefore, solving the above constraints is of paramount importance to improve the goat production potential and livelihood of the farmers in the study area.
\end{abstract}

Keywords: Central highland goats; Constraints; Emba Alaje; Management; Tigray 


\section{Introduction}

There is a rise in the importance of goats in most developing countries (FAO, 2001). Increasing population pressure, land scarcity and diminishing production resources are promoting goat and sheep production in the tropic (Bett et $a l ., 2009)$. The increasing interest in goat keeping observed recently in many developed countries is related to the fact that goat products are considered a delicacy of great nutritional value (Park, 2000). Despite the huge genetic diversity and valuable contributions of goats to the livelihoods of farmers in rural areas, the sector has been given low research and development attention at global and national levels (Mahmoud Abdel Aziz, 2010). This is mainly due to an inadequate recognition of the contributions goats make to the livelihoods of the poor, resulting in underutilization of the diverse goat genetic resources (Mahmoud Abdel Aziz, 2010).

According to the CSA (2013), out of the 54 million livestock population in Ethiopia, goats cover $23.23 \%$. Goats have a significant role in the economy of the country. The country earns annually on average about US dollar 8 million from the export sales of live sheep and goats and of mutton and goat meat. (ILCA, 1991). Despite the large size of the country's goat population, the productivity per goat and the contribution of this sector to the national economy is relatively low. This may be due to different factors such as poor nutrition, prevalence of diseases, lack of appropriate breed and breeding strategies and poor understanding of the production system as a whole. However, the indigenous goat breeds have relative advantage in their natural habitat (Tesfaye Tsegaye, 2009). In Tigray Region, goat rearing is among the livestock production activities where they are kept under extensive production system. Goats have a significant contribution for the economy of livestock keepers and the region as whole. Despite study on goats' management practices and production constraints are important for developing appropriate intervention for improving the productivity and income from keeping goats, there is a study gap in Tigray Region in general and particularly in Emba Alaje District. Therefore, the current study was conducted with the objective of assessing management practices and production constraints of central Highland goats in Emba Alaje District. 


\section{Materials and Methods}

\section{Description of the study area}

The current study was conducted in Emba Alaje District. It is located in the southern zone of Tigray at a longitude and latitude of $39^{\circ} 15^{\prime}$ to $39^{\circ} 35^{\prime} \mathrm{E}$ and $12^{\circ} 51^{\prime}$ to $13^{\circ} 00^{\prime} \mathrm{N}$ at a distance of $100 \mathrm{~km}$ south of Mekelle city. It has an altitude of 2445 to 2480 meters above sea level (m.a.s.l.) and with maximum and minimum rainfall of 845 and $580 \mathrm{~mm}$, respectively. The temperature ranges between $14^{\circ} \mathrm{C}$ and $22^{\circ} \mathrm{C}$ for minimum and maximum values, respectively. Generally, the agro climatic condition of the wereda varies from dega $(2,300-3,300$ masl), woyna dega (1,500 -2,300-masl) and kola (500-1,500-masl). The livestock population of the study area is $76,215,62,148,59,286$ and 218,640 for cattle, sheep, goats, and equine, respectively (BoARD, 2015)

\section{Sampling procedure and data collection}

First, seven representative peasant associations (Ayba, Atsela, Keyhe Tkeli, Kelma, Batmera, Tekea and Fana) out of twenty peasant associations of the study district were purposively selected. The peasant associations were selected based on their goat population and production potential. During the selection process, experts from the Bureau of Agriculture and Rural Development of the district were involved. Next, 250 households from the seven peasant associations who rear goats were randomly selected. Then, qualitative data were collected using pretested and semi-structured questionnaires by face-toface interview. The questionnaire survey was focused on the respondents' biography and socioeconomic characteristics, goat management practices such as housing, feeding, breeding and health and major constraints of goat production. Moreover, data were collected from group focused discussion, and qualitative data were also collected via observations by the researchers during field visits.

\section{Data analysis}

The data collected from the current study were entered into a Microsoft Excel sheet and coded properly. Then, it was imported to a Statistical Package for Social Sciences (SPSS) version 20 for descriptive data analysis such as frequency and percent. 


\section{Results}

\section{Respondents' biography and socioeconomic characteristics}

Out of the total respondents interviewed in the current study, $85.2 \%$ of themwere males, and $38 \%$ of them had a basic education. Almost all (99.6\%) of the respondents practiced a mixed crop livestock production system, and majority of them (85.2\%) reared goats for an immediate cash source (Table 1).

Table 1. Respondents' biography and socioeconomic characteristics

\begin{tabular}{llcc}
\hline Variables & Category & Frequency & Percent (\%) \\
\hline \multirow{4}{*}{ Sex } & Male & 213 & 85.2 \\
& Female & 37 & 14.8 \\
& Illiterate & 41 & 16.4 \\
& Basic education & 95 & 38 \\
& Elementary & 71 & 28.4 \\
& Secondary & 42 & 16.8 \\
Farming activity & Diploma and above & 1 & 0.4 \\
& Crop production & 1 & 0.4 \\
Production system & Mixed crop livestock production & 249 & 99.6 \\
& Intensive & 8 & 3.2 \\
& semi intensive & 1 & 0.4 \\
Purpose of rearing & Extensive & 241 & 96.4 \\
goats & For immediate cash source & 163 & 85.2 \\
& For live animal saving & 68 & 27.2 \\
& For meat source & 18 & 7.2 \\
& For milk source & 1 & 0.4 \\
\hline
\end{tabular}

\section{Housing managements of goats in the study area}

The statistical analysis of the present study indicated that $62.4 \%$ of the total respondents kept their goats only at nights. Moreover, $78.8 \%$ of the respondents had a separate housing for their goats. Majority of the respondents (96.4\%) cleaned the goats' house regularly. However, $96.4 \%$ of the respondents did not have a separate house for pregnant goats (Table 2). 
Table 2. Housing management of goats in the study area

\begin{tabular}{llcc}
\hline Variables & Category & Frequency & Percent (\%) \\
\hline How do you keep your goats at & Housed alone & 156 & 62.4 \\
night? & Housed with sheep & 92 & 36.8 \\
& Housed with cattle & 2 & 0.8 \\
Where do you keep your goats at & In a separate farming & 53 & 21.2 \\
night & area & & \\
& In our residence & 197 & 78.8 \\
& compound & & \\
What type of goats' house do you & Closed type & 239 & 95.6 \\
have? & Open but fenced & 11 & 4.4 \\
Do you clean the house regularly? & Yes & 241 & 96.4 \\
& No & 9 & 3.6 \\
Cleaning frequency of the house & Once & 57 & 22.8 \\
per week & Twice & 146 & 58.4 \\
& Three times & 37 & 14.8 \\
& Four times & 10 & 4 \\
Do you have a separate house for & Yes & 126 & 50.4 \\
does and kids? & No & 124 & 49.6 \\
Do you keep pregnant goats in & Yes & 9 & 3.6 \\
separate house? & No & 241 & 96.4 \\
\hline
\end{tabular}

\section{Feeding management of goats in the study area}

Regarding the feeding management of goats in the study area, majority of the respondents (89.2\%) used a communal grazing/browsing area, since most of them used an extensive production system. Provision of supplementary feeds for goats in the study area was not common, as most respondents (89.6\%) did not give any supplementary feeds to their goats, and none of the respondents (100\%) purchased supplementary feeds for their goats (Table 3). 
Table 3. Feeding management of goats in the study area

\begin{tabular}{llcc}
\hline Variables & Category & Frequency & Percent (\%) \\
\hline Main feed source for goats & Communal grazing/browsing & 223 & 89.2 \\
& area & & \\
& Owned grazing/browsing area & 2 & 0.8 \\
& Both & 25 & 10.0 \\
Provision of & Yes & 26 & 10.0 \\
supplementary feeds & No & 224 & 89.6 \\
Type of supplementary & Straw & 3 & 1.2 \\
feeds & Hay & 11 & 4.4 \\
& Atela & 13 & 5.2 \\
Purchasing feeds for goats & No & 250 & 100 \\
Practicing goat fattening & Yes & 4 & 1.6 \\
& No & 246 & 98.4 \\
Water source for goats & River & 212 & 84.8 \\
& Pound & 19 & 7.6 \\
& Pipe & 19 & 7.6 \\
Watering frequency per & Once & 220 & 88.0 \\
day & Twice & 19 & 7.6 \\
& Once in two days & 11 & 4.4 \\
\hline
\end{tabular}

\section{Breeding and milking management of goats in the study area}

The results of the present study showed that, majority of the respondents (61.65\%) did not select bucks for breeding, and $35.2 \%$ of them did not know the source of the bucks that mate their goats. Generally, $99.2 \%$ of the respondents used uncontrolled breeding.

Goats in the study area served as source of milk for the households, and there was a habit of raw milk consumption. In addition to drinking raw and boiled milk, goats' milk was also processed into butter using a traditional processing technique (25.6\%) (Table 4). 
Table 4. Breeding and milking management of goats in the study area

\begin{tabular}{|c|c|c|c|}
\hline Variables & Category & Frequency & Percent (\%) \\
\hline \multirow[t]{2}{*}{ Do you select buck for breeding? } & Yes & 96 & 38.40 \\
\hline & No & 154 & 61.65 \\
\hline \multirow{3}{*}{$\begin{array}{l}\text { Where is the source buck for } \\
\text { breeding? }\end{array}$} & Own & 48 & 19.00 \\
\hline & Neighboring & 114 & 45.60 \\
\hline & Unknown & 88 & 35.20 \\
\hline \multirow[t]{2}{*}{ Average age at first kidding } & $<1$ year & 127 & 49.20 \\
\hline & $1-1.5$ years & 123 & 83.20 \\
\hline \multirow[t]{3}{*}{ Number of kids per kidding } & Single & 208 & 83.20 \\
\hline & Twine & 41 & 16.40 \\
\hline & Triple & 1 & 0.40 \\
\hline \multirow[t]{2}{*}{ Average kidding interval per year } & One & 5 & 2.00 \\
\hline & Two & 245 & 98.00 \\
\hline \multirow{2}{*}{$\begin{array}{l}\text { Do you milk goats for human } \\
\text { consumption? }\end{array}$} & Yes & 102 & 40.80 \\
\hline & No & 148 & 59.20 \\
\hline \multirow[t]{3}{*}{ Average milk yield per goat } & $<0.5$ Litter & 44 & 17.60 \\
\hline & 0.5-1Litter & 13 & 5.20 \\
\hline & I do not know & 189 & 75.60 \\
\hline \multirow[t]{2}{*}{ Do you drink raw milk? } & Yes & 67 & 26.80 \\
\hline & No & 183 & 73.20 \\
\hline \multirow{2}{*}{$\begin{array}{l}\text { Do you process goats' milk into } \\
\text { butter? }\end{array}$} & Yes & 64 & 25.60 \\
\hline & No & 186 & 74.40 \\
\hline
\end{tabular}

\section{Health management of goats in the study area}

According to the results of the present study, $100 \%$ of the respondents complained that there are diseases that affect the health and production of their goats in the study area. About $33.6 \%$ of the respondents complained that pasteurellosis is among the major goats' diseases in the study area, and $92.8 \%$ of them also complained that there is mortality of goats due to different types of diseases. Moreover, selling and slaughtering of diseased goats is common in the study area (Table 5). 
Table 5. Health management of goats in the study area

\begin{tabular}{llcc}
\hline \multicolumn{1}{c}{ Variables } & Category & Frequency & Percent (\%) \\
\hline $\begin{array}{l}\text { Do you have diseases problem for } \\
\text { your goats? }\end{array}$ & Yes & 250 & 100 \\
What are the common goats' & External parasites & 67 & 26.8 \\
diseases? & Goat pox & 51 & 20.4 \\
& PPR & 48 & 19.2 \\
& Pasteurellosis & 84 & 33.6 \\
What do you do when your goats & I treated them my self & 32 & 12.8 \\
are diseased? & I take them to a & 217 & 86.8 \\
& veterinarian & & \\
& I do nothing & 1 & 0.4 \\
Do you vaccinate your goats & Yes & 222 & 88.8 \\
regularly? & No & 28 & 11.2 \\
What are the common causes of & Diseases & 81 & 32.4 \\
death for your goats? & Draught & 82 & 32.8 \\
& Predators & 84 & 33.8 \\
& Accident when they are & 3 & 1.2 \\
\hline
\end{tabular}

\section{Major constraints of goats' production in the study area}

In the study area, different constraints were identified to affect goat production. Feed shortage (36\%) and diseases (33.6\%) were among the major constraints raised by the respondents. However, according to the results of the current study, $92.8 \%$ of the respondents said that there is a good veterinary service in the study area (Table 6)

Table 6. Major constraints of goat production in the study area

\begin{tabular}{lcc}
\hline Constraints & Frequency & Percent (\%) \\
\hline Feed shortage & 90 & 36.0 \\
Diseases & 84 & 33.6 \\
Market problem & 12 & 4.8 \\
Lack of farming land & 30 & 12 \\
Lack of credit services & 34 & 13.6 \\
\hline
\end{tabular}




\section{Discussion}

The results of the current study indicated that, the main feed source for goats in the study area was from communal grazing/browsing (89.2\%). About $89.6 \%$ of the total respondents did not give supplementary feeds for their goats, implying that majority of them did practice an extensive production system where the goats mainly depended on feeds of the communal grazing/browsing area.

This result was higher than that reported by Manzi (2013), where communal grazing constituted only $5.2 \%$ of the feeds for goats. Moreover, $89.2 \%$ of the respondents did not use supplementary feeds for their goats. Most of the respondents did not purchase feeds for their goats, and this could be due to the fact that most of them did not give supplementary feeds for their goats and due to lack of awareness on the advantages of giving supplementary feeds in increasing and/or improving productivity and health of goats.

Goat fattening was not a common practice in the study area, as $98.6 \%$ of the total respondents did not practice supplementary feeding of goats. About $99.2 \%$ of the respondents use uncontrolled breeding, and selection of the best bucks for breeding was very low. Moreover, $35.2 \%$ of the respondents use buck of unknown source for mating their does. This could be due to the fact that the owners and the children who often keep the goats do not have adequate awareness about the breeding management of their goats.

About $49.6 \%$ of the respondents did not separate kids and does during night and day time, possibly increasing the chance of getting contagious diseases by running the kids with the flock when the new born kids are not immunologically competent. This result is in agreement with the results of Sharif et al (2005), who reported that kids were at higher risk of dying if they were not being separated from adult animals. Therefore, provision of extension services and giving trainings on management practices of goats to the farmers of the study area is very important to improve the production and productivity of their goats and livelihood.

\section{Acknowledgements}

The authors would like to thank for the goat owners and responsible offices of the study area for their significant contribution and cooperation during the data collection process. 


\section{References}

Aziz, A. M., 2010. Present status of the world goat populations and their productivity. Lohmann Info., 45 (2), 42-52.

Bett, R.C., Kosgey, I. S., Kahib, A. K. and Petersa, K.J., 2009. Realities in breed im- provement programmes for dairy goats in East and Central Africa. Small Rum. Res., 85, 157-160.

BoARD (Bureau of Agriculture and Rural development), 2015. Agroecology of Embalaje Wereda, Southern zone, Tigay, Ethiopia.

CSA (Central Statistical Agency), 2013. Agricultural sample survey volume II: Report on livestock and Livestock Characteristics in Ethiopia. Statistical Bulletin 570, Addis Ababa, Central Statistical Agency (CSA), and federal Democratic Republic of Ethiopia.

FAO (Food and Agriculture Organization), 2001. FAOSTAT.FAO production year book, Volume 48. FAO, Rome, Italy.

ILCA (International Livestock Center for Africa), 1991. Hand book of African livestock

Statistics working document No.15, ILCA, Addis Ababa, Ethiopia.

Manzi,T. J., Mutabazi, C. D., Hirwa and Kugonza, D R., 2013. Socio-economic assessment of indigenous goat production system in rural areas of Bugesera District in Rwanda. Livesto. Res. Rural Dev.,25.

Park,Y ., 2000. Comparison of mineral and cholesterol composition of different commercial goats milk products manufactured in USA. Small Rum. Res., 37,115-124.

Sharif, L. and Obiedat, J., 2005. Risk factors for lamb and kid mortality in sheep and goat farms in Jordan. Bulgarian J. Vet. Med., 8, 99-108.

Tsegaye, T., 2009. Characterization of goat production systems and on -farm evaluation of the growth performance of grazing goats supplemented with different protein sources in Metemaworeda, Amhara region. MSc thesis. Haramaya Univrsity,Ethiopia. 